\title{
Resectable Cutaneous Squamous Cell Carcinoma of the Head and Neck
}

National Cancer Institute

\section{Source}

National Cancer Institute. Resectable Cutaneous Squamous Cell Carcinoma of the Head and Neck. NCl Thesaurus. Code C162943.

Cutaneous squamous cell carcinoma of the head and neck that is amenable to surgical resection. 